\title{
PRESERVASI NASKAH KUNO SEBAGAI UPAYA PELESTARIAN BUDAYA BANGSA
}

\author{
Hadira Latiar*
}

\begin{abstract}
This article is titled "Preservation of Ancient Manuscripts as an Effort to Preserve Nation Culture". This research is descriptive qualitative. The purpose of this paper is to combine the concept of ancient manuscripts and conservation efforts. More specifically, this paper will describe the concept of the problems and forms of preservation that can be done. Data collected during the study were analyzed using literature study method. The results of the analysis show that preservation of ancient manuscripts is considered very important as an effort to preserve the nation's culture. The preservation effort of the manuscript has two aspects, namely the preservation of the physical text which is consists of conservation and restoration activities. And the preservation of the text The first aspect consists of consists of digitalization activities, cataloging, philology research and codexology.
\end{abstract}

Keywords: Preservation, preservation of ancient manuscripts, ancient scripts, manuscripts, philology, codexology

\section{Pendahuluan}

Setiap bangsa pasti memiliki catatan mengenai perjalanan bangsanya, tak terkecuali Indonesia. Indonesia sebagai bangsa yang memiliki beragam etnik, suku, dan budaya tentu memiliki catatan panjang mengenai kehidupan bangsanya, sosialnya, adat istiadat, seni budaya dan lain sebagainya. Perjalanan panjang tersebut pasti banyak meninggalkan catatan-catatan yang terangkum dalam naskah-nsakah kuno. Blasius Sudarsono menyatakan bahwa;

"Naskah kuno adalah darah kehidupan sejarah, naskah tulisan tangan ini dapat dianggap sebagai

\footnotetext{
*Mahasiswa Pascasarajana Program Studi Interdisciplinary Islamic Studies Konsentrasi IImu Perpustakaan dan Informasi UIN Sunan Kalijaga Yogyakarta. email: hadira.latiar@gmail.com
} 
salah satu representative dari berbagai sumber lokal yang paling otoritatif dan paling otentik dalam memberikan berbagai informasi sejarah pada masa tertentu. Naskah kuno merupakan salah satu warisan budaya bangsa diantara berbagai artefak lainnya, yang kandungan isinya mencerminkan berbagai pemikiran, pengetahuan, adat istiadat serta perilaku masyarakat masa lalu. Ditemukannya naskah kuno membuktikan perkembangan budaya literasi yang menjadi representasi dari berbagai sumber paling otentik dalam memberikan berbagai informasi sejarah pada masa tertentu". ${ }^{1}$

Naskah kuno tersebut ditulis dalam berbagai bahasa aksara dan bahasa. Naskah kuno sesungguhnya adalah tradisi yang hidup di tengah masyarakat yang merefleksikan kemajuan peradaban (civilization) anak bangsa yang memilikinya. ${ }^{2}$ Naskah kuno-naskah kuno itu berisi tentang ketuhanan, ajaran budi pekerti, sejarah, cerita rakyat, (dongeng, legenda), teknologi tradisional, mantra, silsilah, jimat, syair, politik, pemerintahan, undang-undang, hukum, adat, pengobatan tradisional, hikayat dan lain sebagainya. Dibanding dengan benda cagar budaya lainnya, naskah kuno memang lebih retan rusak, baik akibat kelembapan udara dan air (high humidity and waer), dirusak binatang pengerat (harmful insect, rats, and rodents), ketidakpedulian, bencana alam, kabakaran, pencurian, serta ditambah dengan aktifitas jual beli naskah ke mancanegara yang masih kerap terdengar terjadi di lapangan, ${ }^{3}$ dan masih terabaikannya naskah-naskah kuno di wilayah Indonesia.

Kesadaran bahwa naskah kuno merupakan sumber pengetahuan yang paling otentik tentang jatidiri umat manusia dan

\footnotetext{
${ }^{1}$ Sudarsono, Blasius. Perpustakaan Cinta dan Teknologi. Jakarta: ISIPII, 2009. 13.

2 Faisal Amin. "Preservasi Naskah Klasik." Jurnal Khatulistiwa-Journal of Islamic Studies, 2011: 89.

${ }^{3}$ Susahnya Mengurus Naskah Kuno. Fakultas Adab dan Humaniora UIN Syarif Hidayatullah. Mei 28, 2017. http://fah.uinjkt.ac.id/index.php/profil/15-pojokmanusrip/31-susahnya-mengurus-manuskrip-kuno (accessed Mei 28, 2017).
} 
latar belakang budaya yang dimiliki pendahulunya dapat diwujudkan dalam usaha untuk menjaga, mengkaji, dan melestarikanya. ${ }^{4}$

Pelestarian naskah kuno (manuskrip) merupakan subjek penting bagi Pustakawan, Informasi Ilmuwan, Archivist, Curators, Scholars dan juga untuk berbagai jenis institusi. Masalah pelestarian dokumen langka terus berlanjut sejak manusia memperoleh pengetahuan menulis. Seperti Babilonia, Asyur, Sumeria, Cina atau India; Para ahli Taurat selalu khawatir untuk melestarikan tulisan mereka untuk anak cucu dengan segala cara yang mereka miliki. Para ilmuwan seperti Aristoteles, Ovid dan Horace juga mengkhawatirkan keamanan manuskrip dari serangga. Pelestarian manuskrip adalah masalah serius bagi para penjaga di seluruh dunia. Peletarian naskah kuno adalah metode yang ampuh untuk melestarikan warisan sastra, linguistik, artistik dan budaya. Jadi kegiatan ini merupakan usaha yang mungkin harus dilakukan untuk menyelamatkan harta ini bagi generasi penerus. ${ }^{5}$

Naskah kuno yang terdapat di Indonesia sangatlah banyak, Ismail Husen dalam Faisal mengemukakan angka 5.000 naskah, Chambert-Loir mengemukakan 4.000, dan Russel Jones menyebutkan angka sampai 10.000 naskah. Naskah-naskah tersebut tersebar di berbagai wilayah di Indonesia seperti Pulau Jawa, Bali, Madura, Lombok, Bima, Aceh, Riau, Sumatera Utara, Sumatera Barat, Sumatera Selatan, dan Kalimantan Barat. Bahkan tidak sedikit diantara naskah tersebut tersebar diberbagai negara, seperti Inggris, Jerman, Prancis, Belanda, Malaysia, Singapura, dan Brunei Darussalam. ${ }^{6}$

Bahkah diyakini jumlah naskah kuno yang berada di luar negeri itu lebih banyak dibandingkan dengan yang berada di dalam negeri. Apabila konsep ini diletakkan di dalam konsep kedauatan negara, pelestarian naskah kuno ini wajib dijaga dan dikembangkan demi lestarinya warisan budaya bangsa serta sebagai pengikat nasionalisme. Untuk itu, perlu langkah strategis yang harus didukung

\footnotetext{
${ }^{4}$ Fuad Jabali dalam Faisal Amin. Preservasi Naskah Klasik. (Pontianak: Jurnal Khatulistiwa-Journal of Islamic Studies, 2011), 89.

${ }^{5} J y o t s h a n a$ Sahoo, dan Basudev Mohanty. "Indegeneous of Preserving Manuscripts: An Overview." OHRJ XLVII, no. 3 (n.d.): 1.

${ }^{6}$ Faisal Amin. Preservasi Naskah Klasik...., 90.
} 
karena ini merupakan bentuk penjarahan dan ini menjadi salah satu sumber ancaman keamanan nasional.

Jika hal ini dibiarkan terus terjadi, maka jelas penjarahan naskah kuno telah melanggar undang-undang perlindungan cagar budaya. ${ }^{7}$ Keberadaan naskah kuno sebagai warisan budaya telah dilindungi oleh undang-undang. dimana telah dinyatakan dalam Undang-Undang Republik Indonesia Nomor 11 Tahun 2010 Tentang Cagar Budaya bahwa, Naskah Kuno adalah semua dokumen tertulis yang tidak dicetak atau tidak diperbanyak dengan cara lain, baik yang berada di dalam negeri maupun di luar negeri, yang berumur paling rendah 50 (lima puluh) tahun, dan yang mempunyai nilai penting bagi kebudayaan nasional, sejarah, dan ilmu pengetahuan. ${ }^{8}$ Dalam undang-undang tersebut menegaskan bahwa cagar budaya adalah warisan budaya bersifat kebendaan berupa Benda Cagar Budaya, Bangunan Cagar Budaya, Struktur Cagar Budaya, Situs Cagar Budaya, dan Kawasan Cagar Budaya di darat/atau di air yang perlu dilestarikan keberadaanya karena memiliki nilai penting bagi sejarah, ilmu pengetahuan, pendidikan, agama, dan/atau kebudayaan.

Salah satu permasalahan klasik yang cukup serius adalah masih banyaknya naskah kuno yang masih tersimpan di kalangan masyarakat atau perseorangan. Oleh sebab itu, upaya pengumpulan, penyelamatan, pelestarian dan pemanfaatan naskah kuno menjadi sebuah keniscayaan. (Data tentang naskah kuno). Meskipun demikian, kajian terhadap naskah kuno untuk megungkap sejarah, asal-usul, dan informasi fisik naskah, baik yang menyangkut bahan/alas yang digunakan maupun identitas penyalin, pengarang atau pemiliknya masih belum dapat diskripsikan sehingga masih memerlukan kajian lebih lanjut.

Dari pemaparan tersebut, penulis mencoba menggabungkan konsep naskah kuno dan upaya pelestariannya. Secara lebih spesifik, tulisan ini akan menguraikan tentang konsep permasalahan dan bentuk-bentuk preservasinya yang dapat dilakukan.

${ }^{7}$ Amin Sweeney. "Pernaskahan Melayu dan Masa Depan bangsa Indonesia." Jumanta: Jurnal Manuskrip Nusantara 1, no. 1 (2010): 155.

8 Undang-undang Republik Indonesia Nomor 11 Tahun 2010 Tentang Cagar Budaya. (Jakarta: Dirjen Sejarah dan Purbakala Kementerian Kebudayaan dan Pariwisata, 2010) 


\section{Pembahasan \\ Konsep Pernaskahan}

Dalam tulisan ini ada tiga kunci untuk menjelaskan konsep pernaskahan, yaitu naskah, kadikologi, dan filologi.

\section{Pengertian Naskah}

Naskah diambil dari bahasa Arab, yakni kata al-naskhah yang memiliki padanan bahasa Indonesia berupa kata "manuskrip". ${ }^{9}$ Naskah adalah karangan dengan tulisan tangan yang menyimpan berbagai ungkapan pikiran dan perasaan sebagai hasil budaya bangsa masa lampau. ${ }^{10}$ Kata naskah juga terjemahan dari bahasa latin, yaitu "codex" (bentuk tunggal; bentuk jamak 'codies') yang dalam bahasa Indonesia diterjemahkan menjadi "naskah'-bukan menjadi 'kodeks'. Kata 'codex' dalam bahasa Latin menunjukkan hubungan pemanfaatan kayu sebagai alas tulis yang pada dasarnya kata itu berarti 'teras batang pohon'. Kata 'codex' kemudian diberbagai bahasa dipakai untuk menunjukkan suatu karya klasik dalam bentuk naskah.

Definisi lain yang dapat digunakan di samping istilah naskah adalah 'manuskrip' (dalam bahasa Inggris manuscript). Kata manuscript diambil dari ungkapan Latin codicesmanu scripti, artinya buku-buku yang ditulis dengan tangan. Kata manu berasal dari kata manus, artinya tangan, dan scriptus berasal dari kata scribere, artinya menulis. ${ }^{11}$ Secara harfiah kata manuskrip berarti "tulisan tangan" (writen by hand atau al-makhtuth bi al-yad). Dengan demikian, istilah manuskrip yang biasa disingkat MS untuk naskah tunggal dan MMS untuk naskah jamak adalah dokumen yang ditulis tangan secara manual di atas sebuah media seperti kertas, papirus, daun lontar,

9Oman Fathurrahman. "Pengantar Teori dan Metode Filologi." Handout Presentasi yang disampaikan pada Diklat Peneliti Museum Keagamaan di Kampus Pusdiklat Kemenag RI Jakarta, 26 September s.d 10 Oktober 2011. n.d.

${ }^{10}$ Siti Baroroh Baried,dkk. Pengantar Teori Filologi. (Yogjakarta: Badan Penelitian dan Publikasi Fakultas Sastra UGM, 1994)

${ }^{11}$ Mulyadi, dan Sri Wulan Rujiati. Kodokologi Melayu di Indonesia. (Depok: Fakultas Sastra UI, 1992) 
daluang, kulit binatang, dan lainnya. ${ }^{12}$ Secara umum istilah naskah atau manuskrip ini juga bisa digunakan untuk menyebut informasi yang dibua secara manual pada benda kertas, seperti inskripsi. ${ }^{13}$

Secara etimologis, manuskrip berarti sesuatu yang ditulis tangan. Disini istilah manuskrip yang terkait dengan jaman dahulu tidak harus berarti menulis diserahkan oleh seorang penulis ke penerbit. Benda-benda purbakala yang di dalamnya mencakup manuskrip, catatan atau dokumen lain yang memiliki nilai ilmiah, sejarah, sastra atau estetika dan yang telah ada selama tidak kurang dari tujuh puluh lima tahun. Jika definisi ini dipertimbangkan dalam nilai fasa, manuskrip berarti:

1. sebuah dokumen tertulis tangan

2. yang memiliki ilmiah, sejarah, sastra atau estetika Nilai dan

3. yang berumur paling sedikit tujuh puluh lima tahun. ${ }^{14}$

Dalam kosakata bahasa Indonesia secara umum, kata naskah digunakan tidak terbatas pada dokumen tulis tangan saja, melainkan bisa mencakup dokumen cetak lainnya. Dalam konteks penerbitan, kata naskah dan manuskrip juga sering digunakan untuk menyebut sebuah draft buku yang diserahkan ke penerbitan dan siap untuk dicetak. Dalam kajian Filologi, kata naskah dan manuskrip digunakan secara bergantian dengan pengertian yang sama, yaitu dokumen tulisan tangan kuno.

Pada dasarnya pengertian naskah tidak dibatasi oleh kandungan isinya, ia biasanya berisi paparan teks dalam berbagai bidang yang sangat luas, angka-angka matematis, peta, ilustrasi gambar atau foto, dan lain-lain. Sebuah naskah beriluminasi bias merupakan gabungan indah dari teks, gambar, hiasan pinggir, kaligrafi huruf, atau ilustrasi sepenuh halaman (full-page illustrations). Pada masa lalu, terutama sebelum ditemukan mesin cetak, semua dokumen dihasilkan melalui tulisan tangan, baik

12 Uka Tjandrasasmita. Kajian Naskah-naskah Klasik dan Penerapannya bagi Kajian Sejarah Islam di Indonesia. (Jakarta: Publishing Lektur Keagamaan Badan Litbang dan Diklat Departemen Agama RI, 2006)

${ }^{13}$ Oman Faturahman, Filologi dan Islam Indonesia. (Jakarta: Badan Litbang dan Diklat Puslitbang Lektur Keagamaan, 2010)

${ }^{14}$ Ramesh C Gaur dan Mrinmoy Chakraborrty. Preservation and Access to Indian Manuscripts: A Knowledge Base of Indian Cultural Heritage Resources for Academic Libraries. (India: ICAL, 2009), 
berbentuk gulungan (scroll) papirus atau buku (codex) pada masa berikutnya. Nama tempat di mana naskah-naskah klasik disalin oleh para juru tulis disebut skriptorium (scriptorium) atau skriptoria (bentuk jamak). Pada awalnya 'skriptorium' biasa digunakan untuk menunjuk pada ruangan di dalam biara pada zaman pertengahan Eropa yang ditujukan untuk menyalin manuskrip oleh penulis monastik. $^{15}$

Naskah perlu dibedakan dengan teks, karena kekeliruan membedakan dan memahaminya keduanya akan mengakibatkan kerancuan dalam setiap pembahasan. Jika naskah mengacu pada bundel fisik dokumen kuno, maka teks adalah apa yang terkandung dalam dokumen tersebut. Sebuah naskah bias jadi mengandung satu atau lebih teks, bahkan bias berisi topik atau bidang keilmuan yang sama sekali berbeda satu sama lainnya. Hal ini sangat dimungkinkan karena pada masa lalu, seseorang memiliki bundel naskah yang belum ditulisi terlebih dahulu, sebelum membubuhkan dokumen atau informasi apapun yang mereka miliki dan ingin mereka abadikan dalam bentuk tulisan.

Sebagai benda cagar budaya, keberadaan manuskrip telah dilindungi oleh undang-undang. Hal ini telah dinyatakan dalam Undang-Undang Nomor 5 Tahun 1992 bahwa benda-benda cagar budaya adalah benda-benda buatan manusia, bergerak atau tidak bergerak yang berupa kesatuan atau kelompok atau bagian-bagian atau sisa-sia yang berumur sekurang-kurangnya 50 (lima puluh) tahun, atau mewakili masa gaya yang khas dan mewakili masa gaya sekurang-kurangnya 50 (lima puluh) tahun serta dianggap mempunyai nilai penting bagi sejarah, ilmu pengetahuan dan kebudayaan. $^{16}$

Dalam Undang-Undang Republik Indonesia Nomor 11 Tahun 2010 tentang cagar budaya kembali ditegaskan bahwa cagar budaya adalah warisan budaya bersifat kebendaan berupa Benda Cagar Budaya, Bangunan Cagar Budaya, Struktur Cagar Budaya, Situs Cagar Budaya, dan Kawasan Cagar Budaya di darat dan/atau di air yang perlu dilestarikan keberadaannya karena memiliki nilai penting bagi

\footnotetext{
${ }^{15}$ Faisal Amin. Preservasi Naskah Klasik... 91.

${ }^{16}$ Ahmad Rahman, "Lektur Keagamaan dalam Naskah Klasik Sulawesi Selatan." Jurnal Lektur Keagamaan 8, no. 2 (2009): 184.
} 
sejarah, ilmu pengetahuan, pendidikan, agama, dan/atau kebudayaan.

Kumar dan Leena menyatakan bahwa, selain memiliki informasi (data gambar) manuskrip juga memiliki informasi visual (secondary image data). Informasi mengenai bentuk fisik, pengikatan, kertas, sejarah manuskrip, sumber perolehan, nilai pasar saat ini yang seringkali tinggi, disebut data fisik. Semua ini sangat penting dalam manuskrip. ${ }^{17}$

\section{Pengertian Kadikologi}

Menurut Hermans dan Huisman dalam Faisal, istilah codicologie diusulkan oleh seorang ahli bahasa Yunani, Alphonse Dain, dalam kuliah-kuliahnya di Ecole Normale Seprieure, Paris, pada bulan Februari 1944. Akan tetapi istilah ini baru terkenal pada tahun 1949 ketika karyanya, Les Manuscrits' diterbitkan pertama kali pada tahun tersebut. Alphonse Dain sendiri mengatakan bahwa kodikologi adalah ilmu mengenai naskah-naskah dan bukan mempelajari apa yang tertulis di dalam naskah. Alphonse Dain juga menegaskan walaupun kata kodikologi itu baru, ilmu kodikologinya sendiri bukanlah hal yang baru. Selanjutnya Alphonse Dain juga mengatakan bahwa tugas dan - daerah kodikologi antara lain ialah sejarah naskah, sejarah koleksi naskah, penelitian mengenai tempat naskah yang sebenarnya, masalah penyusunan katalog, penyusunan daftar katalog, perdagangan naskah, dan penggunaan naskah itu. ${ }^{18}$

Hal awal yang biasanya dilakukan dalam analisis kodikologi adalah menelusuri sejarah naskah. Sejarah naskah biasanya didapat dari catatan-catatan di halaman awal/ akhir yang ditulis oleh pemilik/ penyimpan naskah itu. Fisik naskahnya, yang dilihat adalah panjang, lebar, ketebalan naskah keseluruhan, panjang, lebar, dan jumlah halaman yang digunakan untuk menulis, dan bahan atau media naskah.

Setelah hal-hal di atas, kodikologi masuk ke bagian dalam naskah, yaitu bagian naskah yang ditulisi atau teks. Di sini kodikologi akan melihat jenis huruf dan bahasa yang digunakan, ada atau

${ }^{17}$ S kumar dan Leena Shah. "Digital Preservation of Manuscripts: A Case Study." 2nd Convention Planner-2014. (Manipur Uni Imphal: INFLIBNET, 2004), 1.

${ }^{18}$ Faisal Amin. Preservasi Naskah Klasik... 93. 
tidaknya rubrikasi atau penanda awal dan akhir bagian dalam tulisan (biasanya berupa tulisan yang diwarnai berbeda dengan tulisan isi), ada atau tidaknya catchword/kata pengait yang biasanya digunakan untuk menandai halaman naskah, \& bentuk tulisan naskah, apakah seperti penulisan cerita pada umumnya, ataukah berbentuk kolomkolom hingga dalam satu halaman bisa terdapat dua atau lebih kolom tulisan (seperti syair). Selanjutnya kodikologi mengecek garis bantuan yang digunakan untuk mengatur tulisan, cap kertas (watermark dan countermark) yang menandai perusahaan penghasil kertas alas, ada atau tidaknya iluminasi (hiasan di pinggir naskah) dan ilustrasi (bagian yang berisikan gambar keterangan yang menjelaskan sesuatu dalam naskah). Kodikologi juga mencatat kerusakan-kerusakan yang ada pada manuskrip. ${ }^{19}$

\section{Pengertian Filologi}

Secara etimologis, filologi berasal dari dari bahasa Yunani dab terdiri dari dua kata, yaitu philos yang berarti - yang tercinta (loved, beloved, dear, friend) dan logos yang berarti - kata, artikulasi, alasan (ward, articulation, reason). Kata filologi mulai masuk dalam kosa kata bahasa Inggris pada abad ke-16 dalam pengertian -love of literature (menyukai kesusasteraan). Istilah dalam bahasa Latin, philologia dapat juga diartikan -love of learning (senang belajar). Mulai abad ke-19, istilah -love of learning and literature juga dipahami dalam pengertian sebagai kajian atas sejarah perkembangan bahasa (the study of the historical development of languages). ${ }^{20}$

Dalam pengertian umum, istilah Filologi dapat dianggap sebagai salah cabang dari ilmu-ilmu humaniora yang memfokuskan perhatian pada aspek bahasa dan sastra, terutama yang termasuk dalam kategori bahasa dan sattra klasik. Namun dalam pengertian yang lebih khusus, istilah Filologi merujuk pada cabang ilmu yang mengkaji teks beserta sejarahnya (tekstologi), termasuk di dalamnya melakukan kritik teks yang bertujuan untuk merekonstruksi keaslian

\footnotetext{
${ }^{19}$ Ibid, 94.

${ }^{20}$ Siti Baroroh Baried,dkk. Pengantar Teori Filologi... 2.
} 
sebuah teks, mengembalikannya pada bentuk semula, serta membongkar makna dan konteks yang melingkupinya. ${ }^{21}$

Filologi terkadang juga dihubungkan dengan metode kajian teks yang disebut higher criticism, yakni sebuah metode telaah teks yang bertujuan untuk memverifikasi kebenaran nama pengarang, tanggal penulisan, dan asal-usul teks. Metode ini dengan sendirinya akan menghubungkan Filologi dengan telaah atas konteks teks yang dikajinya. Hanya saja dalam model seperti ini, seorang peneliti sering kali dihadapkan pada pilihan untuk juga melakukan interpretasi atas teksnya, sehingga perlu kehati-hatian ekstra agar ia tidak terlalu jauh melakukan penafsiran. Hal itu disebabkan filologi pada dasarnya berusaha menelusuri obyektifitas, sementara bentuk-bentuk penafsiran (interpretation) meniscayakan subyektifitas. ${ }^{22}$

Dalam konteks ini, James Lockhart dan beberapa sarjana lainnya yang tergabung dalam mazhab Filologi Baru (New Philology) menolak sama sekali penelitian dengan menggunakan metode kritik teks yang disertai penafsiran, karena menurut pendapat mereka metode ini dapat merusak integritas teks melalui penafsiran yang dibuat oleh peneliti, sehingga pada akhirnya dapat mengacaukan keabsahan data di dalamnya. ${ }^{23}$ Mazhab Filologi Baru ini merekomendasikan metode diplomatik dalam penelitian Filologi yang dilakukan dengan cara menampilkan teks apa adanya, tanpa ada koreksi teks (emendation) dari peneliti sama sekali. ${ }^{24}$

Sementara mazhab Filologi Baru, ada mazhab Filologi Tradisional yang beranggapan bahwa jika terdapat variasi bacaan dalam sebuah salinan, maka telah terjadi kesalahan dan kekeliruan (errors) dari penyalin yang mutlak harus diluruskan, sehingga manuskrip yang menggandung kesalahan tersebut disebut sebagai manuskrip yang rusak (corrupt). Meskipun demikian, sebahagian pengkaji yang lain berpendapat bahwa variasi bacaan yang terdapat dalam salinan naskah manuskrip merupakan sebuah kreasi penyalin sesuai dengan konteks ruang dan waktunya masing-masing. Sebagi konsekuensinya, variasi bacaan tersebut tetap patut diapresiasi sebagai hasil resepsi sang penyalin atas teks asal yang menjadi

\footnotetext{
${ }^{21}$ Oman Faturrahman, Filologi dan Islam Indonesia,... 8.

${ }^{22}$ Faisal Amin. Preservasi Naskah Klasik... 95.

${ }^{23}$ Oman Faturrahman, Filologi dan Islam Indonesia... 11.

${ }^{24}$ Faisal Amin. Preservasi Naskah Klasik... 96.
} 
rujukannya. Pandangan ini telah melahirkan mazhab Filologi Modern. $^{25}$ Dengan demikian, Filologi Tradisional memiliki kecenderungan untuk berusaha menemukan bentuk mula teks, atau setidaknya merekonstruksi teks agar terbentuk sedekat mungkin aslinya, sedangkan Filologi Modern lebih mengarahkan hasil kerjanya untuk menemukan makna kreasi penyalin seperti tampak dalam versi teks yang dijumpainya.

Ilmu Filologi mengasumsikan bahwa dalam benda cagar budaya yang disebut naskah itu tersimpan beraneka ragam informasi menyangkut buah pikiran, perasaan, kepercayaan, adat istiadat, kegiatan sehari-hari, ajaran dan berbagai informasi lainnya yang terkait sebuah masyarakat tertentu pada masa lampau. Berbagai kandungan isi dalam naskah itulah yang kemudian disebut sebagai teks, dan menjadi obyek kajian Filologi. ${ }^{26}$

Dari kajian filologi diketahui manuskrip-manuskrip Indonesia terbagi atas 14 kategori, yaitu (1) naskah keagamaan, (2) naskah kebahasaan, (3) naskah filsafat dan folklore, (4) naskah mistik rahasia, (5) naskah mengenai ajaran moral, (6) naskah mengenai peraturan dan pengalaman hukum, (7) naskah mengenai silsilah raja-raja, (8) naskah mengenai bangunan dan arsitektur, (9) naskah mengenai obat-obatan, (10) naskah mengenai arti perbintangan, (11) naskah mengenai ramalan, (12) naskah susastra, (13) naskah bersifat sejarah, dan (14) naskah mengenai perhitungan waktu. ${ }^{27}$

\section{Preservasi Naskah Kuno}

Istilah pelestarian atau preservation tidak hanya mencakup semua aspek usaha dalam melestarikan bahan pustaka dan arsip tetapi mencakup juga dalam aspek naskah, termasuk di dalamnya tentang kebijakan pengalolaan, keuangan, sumber daya manusia, metode dan teknik, serta penyimpanan. Artinya bahwa pelestarian naskah menyangkut pelestarian dalam bidang fisik tetapi juga pelestarian dalam bidang informasi yang terkandung di dalamnya. ${ }^{28}$

\footnotetext{
${ }^{25}$ Siti Baroroh Baried,dkk. Pengantar Teori Filologi... 6.

${ }^{26}$ Ibid.

${ }^{27}$ Trigangga dalam Faisal , Preservasi Naskah Klasik... 95.

${ }^{28}$ F. N Hidayah. "Pelestarian Bahan Pustaka di UIN Sultan Syarif Kasim Riau." Buletin Perpustakaan UIN Suska Riau 4, no. 6 (2010): 8.
} 
Dalam strategi pelestarian (preservasi) naskah kuno, terdapat dua pendeatan yang dilakukan, yaitu pendekatan terhadap fisik naskah dan pendekatan terhadap teks dalam naskah (isi naskah). ${ }^{29}$ Sedangkan dalam ruang lingkup pernaskahan, pelestarian (preservasi) merupakan pekerjaan untuk memelihara dan melindungi naskah sehingga tidak mengalami kerusakan fisik dan sekaligus memelihara warisan budaya bangsa serta bisa dimanfaatkan dalam jangka waktu yang lama. Preservasi manuskrip atau pemeliharaan naskah sebagai bentuk pelestarian itu diletakkan secara linier dengan pengertian naskah klasik atau manuskrip. Preservasi naskah mencakup dua aspek, yaitu preservasi fisik naskah dan preservasi teks dalam naskah. Aspek pertama terdiri dari kegiatan konservasi dan restorasi. Sedangkan aspek kedua terdiri dari kegiatan digitalisasi, katalogisasi, dan riset filologi. ${ }^{30}$

Preservasi naskah kuno lebih ditujukan pada pemeliharaan agar bentuk fisik naskah tersebut tetap utuh dan tidak rusak, cara yang bisa dilakukan yaitu dengan melakukan konservasi dan restorasi. Konservasi yaitu upaya perpanjangan usia naskah, yang dapat dilakukan dengan beberapa cara diantaranya; Difumigasi minimal satu tahun sekali, Disimpan dalam ruang khusus dengan suhu \pm 16 o $\mathrm{C}$ (24 Jam) Kelembaban Udara antara 50-55\%. Sebagai Benda Cagar Budaya yang disimpan di museum, koleksi kertas merupakan jenis koleksi yang paling peka terhadap kondisi lingkungan, baik kondisi fisis, kimia, maupun biotis. ${ }^{31}$ Kertas akan mengalami perubahan warna atau pemudaran, yang dikenal dengan istilah fotolisa atau reaksi fotokimia akibat faktor fisis, akibat faktor kimiawi akan mengalami keasaman, sedangkan akibat faktor biotis seperti pertumbuha jamur mengakibatkan kertas menjadi lapuk. Masalah lain yang perlu diperhatikan terkait konservasi kertas adalah tinta yang digunakan untuk menulis dokumen, ada jenis tinta yang tidak larut dalam air, ada yang sebagian yang larut, dan ada pula tinta yang larut seluruhnya.

Langkah awal yang harus dilakukan untuk penanganan konversari kuratif adalah mula-mula melakukan pembersihan secara

${ }^{29}$ Y. Primadesi. "Peran Masyarakat Lokal dalam Usaha Pelestarian Naskahnaskah Kuno Paseban." Jurnal Bahasa dan Seni II, no. 2 (2010): 121.

${ }^{30}$ Oman Fathurrahman, Filologi dan Islam Indonesia... 11.

${ }^{31}$ Bidharja dalam Faisal, Faiasal , Preservasi Naskah Klasik... , 96. 
mekanis untuk menghilangkan akumulasi debu dan kotoran yang menempel pada permukaan kertas. Selanjutnya dilakukan fumigasi dalam ruang tertutup rapat untuk membunuh jenis-jenis serangga dalam segala tingkatannya, khususnya tingkatan telur dan larva dengan menggunakan bahan kimia. Setelah selesai tindakan fumigasi, koleksi kertas dikeluarkan dan diangin-anginkan dalam ruangan tanpa cahaya.

Selanjutnya dilakukan pengujian terhadap keasaman kertas dan pengujian terhadap kualitas tinta yang digunakan untuk mengetahui apakah jenis tinta tersebut larut, tidak larut, atau larut sebagian dalam air. Hal ini berguna untuk menentukan metode yang digunakan apakah metode pencucian, penyemprotan, atau menggunakan penciucian dengan gas. Apabila dari hasil pengujian jenis tinta yang digunakan tidak larut dalam air maka digunakan metod epencucian, sementara itu apabila tintanya bersifat larut sebagian maka digunakan metode penyemprotan, sedangkan apabila tinta yang digunakan larut dalam air maka digunakan metode pencucian dengan gas. Tahap berikutnya yang perlu dilakukan adalah dengan cara laminasi, atau jika diperlukan dengan cara konsolidasi menggunakan bahan thermoplastic yang bersifat reversible.

Selain melakukan konservasi, pelestarian fisik naskah yang bertujuan untuk pemeliharaan agar bentuk fisik suatu naskah agar tetap utuh dan tidak rusak adalah melakukan restorasi. Restorasi adalah upaya merawat dan mengembalikan keutuhan kertas dan jilidannya sehingga diharapkan bisa bertahan lebih lama.

\section{Metode Preservasi Naskah Kuno}

Pelestarian teks dalam naskah merupakan suatu upaya melestarikan teks-teks yang terkandung di dalamnya melalui pembuatan salinan (backup) dalam media lain, sehingga paling tidak kandungan isi khazanah naskah itu tetap dapat dilestarikan meskipun seandainya fisik naskahnya musnah akibat rusak atau bencana. Menurut Kumar dan Leena bahwa ada alternatif yang tepat yang bisa menjadi solusi dalam menangani naskah kuno, salah satunya yaitu dengan pelestarian dengan cara microform atau penggunaan 
teknologi komputer modern yang sering diebut digitalisasi manuskrip. ${ }^{32}$

Beberapa cara yang dapat dilakukan adalah: Pertama, digitalisasi. Pelaksanaan digitalisasi naskah atau dokumen dapat menggunakan dua jenis alat kamera dan mesin scanner. Kedua, disalin Ulang. Hal ini merupakan suatu upaya yang dilakukan agar isi informasi dalam suatu informasi dapat diselamatkan dan informasi yang terkandung dapat di akses walaupun keadaan fisiknya telah rusak atau telah hilang. Ketiga, dialihaksarakan. Dengan dialih aksarakannya naskah diharapkan orang yang tidak bias membaca naskah dalam aksara arab atau jawa masih dapat mengakses dan membaca suatu naskah. Keempat, Diterjemahkan. Penerjemahan suatu naskah diperlukan agar orang atau pencari informasi bisa mempelajari suatu naskah walau tidak dapat membaca aksara dan sastra yang tertulis.

Sementara itu, berbagai upaya pemeliharaan (preservasi) naskah kuno tulisan tangan telah dilakukan berbagai pihak, khususnya oleh perpustakaan dan lembaga arsip penyimpan naskah. Upaya tersebut mencakup restorasi, konservasi, dan pembuatan salinan (backup) naskah dalam bentuk media lain. Pada tahun 1980an hingga akhir tahun 1990-an, upaya pembuatan salinan naskah dilakukan melalui media microfilm. Seiring dengan perkembangan teknologi digital, aktivitas alih media naskah pun mengalami revolusi penting pada awal milenium kedua, yakni dengan digunakannya teknologi digital dalam pembuatan salinan naskah, baik melalui kamera digital maupun mesin scanner.

Secara kelembagaan, Perpustakaan Nasional (Perpusnas) barangkali merupakan lembaga pertama yang melakukan program digitalisasi naskah-naskah Nusantara. Sejak dicanangkannya program digitalisasi naskah pada sekitar tahun 2003, dan mulai intensif pada tahun 2006, hingga tahun 2009, Perpusnas sudah mendigitalisasi kurang lebih 1.300 naskah. Sementara itu, hingga akhir tahun 2009 ini, konon Puslitbang Lektur Keagamaan, Badan Litbang dan Diklat, Kementrian Agama telah berhasil mendigitalisasi tidak kurang dari 500 naskah keagamaan Nusantara, yang berasal dari berbagai

${ }^{32}$ S kumar dan Leena Shah. Digital Preservation of Manuscripts: A Case Study,... 1. 
daerah, seperti Selawesi Selatan, Sumatra Barat, Jawa Barat, Banten, dan lainnya. Pada level universitas, Perpustakaan Fakultas IImu Kebudayaan (FIB), Universitas Indonesia (UI) Depok mungkin juga dapat dianggap sebagai yang pertama melakukan progam digitalisasi naskah kuno tersebut dengan sekitar 1.962 judul telah didigitalisasi.

Pengalaman digitalisasi naskah Nusantara yang dilakukan kalangan masyarakat, peneliti, dan pemerhati naskah Nusantara, harus diakui jauh lebih dinamis dibanding dengan apa yang dilakukan pada level lembaga. Namun persoalannya adalah adalah bahwa Perpusnas, dan mungkin Arsip Nasional, sebagai lembaga representasi Negara yang bertanggung jawab dalam penyimpanan dokumen-dokumen penting bangsa ini, belum terlibat dalam berbagai kegiatan digitalisasi naskah Nusantara tersebut, sehingga siapa pun lembaga atau masyarakat yang melakukannya, kedua lembaga Negara ini dapat turut menyimpan salah satu set salinan digital naskah dari setiap program digitalisasi yang dilakukan, seperti halnya terjadi pada program pembuatan microfilm pada tahun 19801990an. Jika tidak, koleksi digital naskah Nusantara di Perpustakaan Nasional dan Arsip Nasional akan kalah lengkap dibanding koleksi Perpustakaan the British Library, Leipzig University, atau lembaga asing penyandang dana lainnya.

\section{Kesimpulan dan Rekomendasi}

Banyaknya naskah klasik yang masih tersimpan di kalangan masyarakat atau perseorangan merupakan realitas yang mengharuskan adanya upaya penyelamatan, pelestarian, dan pemanfaatan. Kondisi ini menuntut adanya upaya preservasi naskah klasik itu dari kepunahan, baik karena dimakan usia ataupun karena ulah oknum yang hanya mementingkan kepentingan ekonomi semata. Upaya preservasi manuskrip atau pemeliharaan naskah kuno atau manuskrip mencakup dua aspek, yaitu preservasi fisik naskah dan preservasi teks dalam naskah. Aspek pertama terdiri dari kegiatan konservasi dan restorasi. Sedangkan aspek kedua terdiri dari kegiatan digitalisasi, katalogisasi, dan riset filologi. Dalam konteks inilah diperlukan usaha bersama dari lembaga lembaga yang terkait dengan preservasi naskah klasik untuk membangun suatu sistem yang memungkinkan manuskrip-manuskrip Nusantara yang jumlahnya sangat banyak dapat diakses dengan mudah. Hal ini perlu 
segera dilakukan karena, penggunaan manuskrip sebagai sumber penelitian adalah salah satu cara yang paling efektif untuk mengklaim orisinalitas di dunia akademik.

\section{Daftar Pustaka}

Amin, Faisal. "Preservasi Naskah Klasik." Jurnal Khatulistiwa-Journal of Islamic Studies, 2011: 89.

Baried, Siti Baroroh. Pengantar Teori Filologi. Yogjakarta: Badan Penelitian dan Publikasi Fakultas Sastra UGM, 1994.

Fathurahman, Oman. "Pengantar Teori dan Metode Filologi." Handout Presentasi yang disampaikan pada Diklat Peneliti Museum Keagamaan di Kampus Pusdiklat Kemenag RI Jakarta, 26 September s.d 10 Oktober 2011. n.d.

Fathurrahman, Oman. Filologi dan Islam Indonesia. Jakarta: Badan Litbang dan Diklat Puslitbang Lektur Keagamaan, 2010.

Gaur, Ramesh C., and Mrinmoy Chakraborrty. Preservation and Access to Indian Manuscripts: A Knowledge Base of Indian Cultural Heritage Resources for Academic Libraries. India: ICAL, 2009.

Hidayah, F. N. "Pelestarian Bahan Pustaka di UIN Sultan Syarif Kasim

Riau." Buletin Perpustakaan UIN Suska Riau 4, no. 6 (2010): 8.

Kumar, S, and Leena Shah. "Digital Preservation of Manuscripts: A Case Study." 2nd Convention Planner-2014. Manipur Uni Imphal: INFLIBNET, 2004. 1.

Mulyadi, and Sri Wulan Rujiati. Kodokologi Melayu di Indonesia. Depok: Fakultas Sastra UI, 1992.

Primadesi, Y. "Peran Masyarakat Lokal dalam Usaha Pelestarian Naskah-naskah Kuno Paseban." Jurnal Bahasa dan Seni II, no. 2 (2010): 121.

Rahman, Ahmad. "Lektur Keagamaan dalam Naskah Klasik Sulawesi

Selatan." Jurnal Lektur Keagamaan 8, no. 2 (2009): 184.

Sahoo, Jyotshana, and Basudev Mohanty. "Indegeneous of Preserving Manuscripts: An Overview." OHRJ XLVII, no. 3 (n.d.): 1. 
Sudarsono, Blasius. Perpustakaan Cinta dan Teknologi. Jakarta: ISIPII, 2009.

"Susahnya Mengurus Naskah Kuno." Fakultas Adab dan Humaniora UIN Syarif Hidayatullah. Mei 28, 2017. http://fah.uinjkt.ac.id/index.php/profil/15-pojok-manusrip/31susahnya-mengurus-manuskrip-kuno (accessed Mei 28, 2017).

Sweeney, Amin. "Pernaskahan Melayu dan Masa Depan bangsa Indonesia." Jumanta: Jurnal Manuskrip Nusantara 1, no. 1 (2010): 155.

Tjandrasasmita, Uka. Kajian Naskah-naskah Klasik dan Penerapannya bagi Kajian Sejarah Islam di Indonesia. Jakarta: Publishing Lektur Keagamaan Badan Litbang dan Diklat Departemen Agama RI, 2006.

Undang-undang Republik Indonesia Nomor 11 Tahun 2010 Tentang Cagar Budaya. Jakarta: Dirjen Sejarah dan Purbakala Kementerian Kebudayaan dan Pariwisata, 2010. 